\title{
The Politics of Health Care Reforms in Kenya and their Failure ${ }^{1}$
}

\author{
Daniel KÜNZLER² \\ University of Fribourg
}

\begin{abstract}
The current literature on the politics of social policy has two major shortcomings: health care reforms are undertheoretized and research on Anglophone Africa tends to neglect health reforms. To tackle this, a case study on Kenya presents (failed) reforms such as universal or categorical free health care or the introduction of health insurance and the expansion of its coverage. The case study clearly shows that there is no single theoretical explanation of social policy reforms or their failure. Rather, there are different combination of factors at work in Kenya.
\end{abstract}

Keywords: health, politics of social policy, Kenya

\section{Introduction}

It is generally agreed that health problems and health-related expenses are important factors associated with the descent into poverty (see e.g., Krishna et al. 2006; Otieno Ajwang' 2013: 236). Health problems lead to short-term loss of earnings or a permanently decreased ability to make a living. Health-related expenses can push people to sell assets like small animals or crops to cover the costs; this might happen directly or indirectly through debt. Selling assets in turn can diminish people's capacity to sustain themselves. Governments use instruments such as free basic health care or health insurance to facilitate access to health care for its population (see e.g., Mbugua et al. 1995 for the effect of lower user costs on health care demand in Kenya). Health insurance is also offered by the private and the non-governmental sector. The latter also might offer free health care.

There is quite a lot of research on the politics of health care reform in Francophone West Africa (e.g., the studies of six countries presented in Ridde et al. 2012). However, this research is mostly concerned with public health and less with theoretical explanations of policy reforms. In contrast, it is astonishing how little research has been done in Anglophone Africa on

\footnotetext{
${ }^{1}$ An earlier version of this paper has been presented in June 2015 at the workshop "The Politics of Social Protection in Africa“ at the University of Cape Town. The author acknowledges valuable feedback by participants of this workshop and a reviewer.

${ }^{2}$ Daniel Künzler, Dr., University of Fribourg, Department of Social Sciences, Route des Bonnesfontaines 11, CH-1700 Fribourg, daniel.kuenzler@unifr.ch. Daniel Künzler is lecturer in sociology, social policy and social work at the University of Fribourg. His publications on Kenya have been published in Africa Spectrum and forthcoming in International Social Security Review.
} 
this. Here, research focuses far more on (social) pension reforms and reveals some theoretical insights in the political processes behind such reforms that might be useful also for health care reforms.

This contribution aims at tackling the undertheoretization of health care reforms and the neglect of research into health reforms in Anglophone Africa. It does so by presenting a case study on Kenya that is guided by the following research question: What are the politics of (failed) health care reforms in Kenya ${ }^{3}$ The case study is based on the existing literature and research in Kenya on health reforms since 2013. It is thus more exhaustive on recent developments. In a first step, theoretical explanations for policy reforms, their undoing and failure are discussed. The following steps focus on reforms related to universal or categorical free health care, to introduction of health insurance and the expansion of its coverage. The case study clearly shows that there is no single explanation of social policy reforms or their failure and there are different combination of factors at work.

\section{Theoretical explanations for reforms, their undoing and failure}

Five arguments are generally used in the literature in order to explain social policy reforms and subsequently presented: the influence of donors, the veto of powerful policy actors, electoral competition, cross national policy learning and windows of opportunities. "Windows of opportunity" are seen as crucial for social policy reforms (e.g., Meessen et al. 2011 for health reforms), but less frequently defined than invoked. A window of opportunity presents itself when, „from the decision-makers' point of view (...) they are to be seen to be taking action, and the political costs of doing so are likely to be low and the benefits potentially high" (Buse et al. 2008: 4). However, there is no such thing as an elaborated theory of windows of opportunity in Kenya, or in similar contexts (see Keeler 1993 for the US-American context). Some insights can be gained from the concept of political opportunity structures that is used in social movement research. Tarrow (1994: 85), for example, defines political opportunities as „consistent - but not necessarily formal or permanent - dimensions of the political environment” that affect „expectations for success or failure”. While he was writing about successful or failed collective action, the focus here is on policy reforms. Examples for such dimensions are the structure or the openness of the political system as emphasized by Meyer (2004). Both the structure and the openness of the political systems drastically changed at independence or with the end of minority rule (Hickey 2009). Changes of government after elections or peace settlements after civil wars (Hickey 2009; Cometto et al. 2010) do also open up windows of opportunity. So do available resources as a consequence of an economic boom or donor promises (for examples see, e.g., Picard 1987). However, Bender (2013: 36) reminds us that economic growth might facilitate reforms without necessarily causing them.

Another explanation for policy reforms emphasizes cross-national policy learning, mainly from neighbouring countries (e.g., Casey and McKinnon 2009 for social pensions in Southern Africa). Again, this is a notion that is far more used than defined, and the conditions necessary for policy learning to happen are frequently unclear. Hall (1993) distinguishes first-, sec-

\footnotetext{
${ }^{3}$ For a study on other aspects of social protection in Kenya, see Künzler (forthcoming).
} 
ond- and third-order policy change. First-order change is limited to small adjustments of existing policy instruments, second-order change is a modification of the instruments within constant policy goals. In both cases, policy learning is likely to be rather technically and driven by bureaucrats. In contrast, third-order change is a shift in policy goals and thus involves political and social actors. Schmid and Götze (2009: 23) distinguish between policymakers searching for general ideas (ideational learning), for details of specific policy instruments (instrumental learning), and for ideas facilitating the implementation of policies (strategic learning). Policymakers might draw lessons from what worked in other countries (positive learning) or what did not work (negative learning). However, both forms of cross-national learning are difficult (Schmid and Götze 2009: 23). On one hand, policies are context-specific and thus not fully replicable. On the other hand, policy learning is frequently more selective than assumed and mainly used as justification of politics based on domestic interests. Finally, similar policy reforms are not necessary the result of policy learning, but might also emerge out of "parallel thinking" (Marmor, Freeman and Okma 2005: 337). A neighbourhood effect is also assumed by diffusion theory (Weyland 2005).

Beyond drawing lessons from them, policy changes in neighbouring countries may also be taken up by political or civil society actors to generate reform pressure on governments or parties (D'Arcy 2013). More generally, social policy reforms are frequently triggered by electoral competition, which is on the rise with democratisation (Hickey 2010; Bender 2013). This coincidence of expenditures in general (Block 2002), and social expenditures in particular (Niles 1999), with elections is the core of the theory of political business or election cycles. There are two theoretical foundations for this approach (Block 2002). The partisan approach is less relevant to the sub-Saharan African context, as here the political parties are less clearly situated on a left-right continuum and incumbents differ less on ideological policy preferences. The traditional second approach is based on a utilitarian conception of politicians: Remaining in power is their only preference. While incumbents are thus in the focus of both theoretical explanations, they are also tacitly applied to elections in general. This bears the danger of linking all reforms to elections, as in a five year elections cycle, many are introduced either just after elections or before them.

Social policy reforms might indeed deliver a high political return for politicians in a context where, generally, the median potential voter is poor (e.g., Carbone 2011 for the health policy reforms in Ghana). However, as Feng and Gizelis (2002) argue, social policy reforms might target less the poorest parts of the population, but those critical for the regime (e.g., regional power base, civil servants). Furthermore, there are very competitive elections without reforms (e.g., Seekings 2013: 318 for the first democratic elections in Zimbabwe). Additionally, there are social policy reforms in countries with limited political competition (Niles 1999; Feng and Gizelis 2002) or in autocracies (Devereux and White 2010; Bender 2013; D'Arcy 2013). Even in a monarchy such as Swaziland, the King introduced in 2005 an Old Age Grant (Ellis et al. 2006). In these less democratic systems, reforms might attempt to broaden the support base or prevent social unrest. However, the theory of political business or election cycles can hardly explain failed reform attempts.

According to Niles (1999: 10f.), social policy reforms are more likely in stable party systems and elected authoritarian systems, less likely in democracies with fragmented party sys- 
tems where parties „cater to narrow interests” and least likely in non-electoral regimes. Kenya is described by Devereux and White (2010: 63) as an "elected authoritarian system" that is „likely to seek electoral advantage by raising social spending during election years”. It is rather unconvincing to put Kenya in the same box as Ethiopia or Uganda. Since the introduction of multi-party elections and especially after 2002, Kenya is clearly an example of a fragmented party system where reforms should be unlikely. Indeed, parties are generally highly personalised and have a strong ethnic appeal (Elischer 2010: 220). Voters do link expected gains of their voting behaviour rather to ethnicity than to policy reforms, and thus social spending (Gutiérrez-Romero (2010: 3). There is not much evidence that prospective social policy issues affect voting behaviour. Health was not mentioned as a central concern of voters in exit polls (Ferree et al. 2014; Lynch 2014), even though it was a consistent issue in the electoral manifestos, not only of the two big coalitions, but also of some smaller parties and coalitions. However, Kenyans strongly doubted not only the financial feasibility of the electoral pledges, but also the winning coalition's interest and capacity to implement them (Künzler 2014). Other researchers have found some evidence that voting is based to a certain extent on retrospective policy and performance evaluation of candidates (Bratton and Kimenyi 2008: 273; Gĩthĩnji and Holmquist 2008: 345). In some contexts, a retrospective evaluation of a social policy reform might cause two effects working in opposite directions: (Potential) beneficiaries might expand an incumbent's electoral base, alienated middle class core supporters might move to the opposition (Corrêa and Cheibub 2016).

Failed reform attempts are sometimes explained by the veto of powerful policy actors, such as the Minister of Finance in Uganda, who blocked a reform project because of its „donor-led character" and concerns over its affordability (Hickey et al. 2009: 65). Political elites might also favour the „deserving” economically active poor and be reluctant to support social policy reforms fearing they create dependency (Devereux and White 2010: 63; see also Hickey 2010: 253). In analogy to the notion of drivers used for policy actors supportive of social policy reforms, there are thus also breakers (or spoilers, as they are called in development cooperation). Similar to several of the other approaches mentioned, the reference to veto powers is generally an ex post explanation, not based on a coherent theory.

The same is true for another explanation for social policy reforms or their absence: the influence of donors. The evidence is ambiguous. ${ }^{4}$ Donors pushed for social policy reforms when imposing structural adjustment and conditionalities on African countries (D’Arcy 2013: 221), or when promoting cash transfers in recent years (Seekings 2013: 318). They are also likely to be influential in post-conflict settings (Cometto et al. 2010). Furthermore, donors can be in opposition to social policy reforms (Cometto et al. 2010; Devereux and White 2010: 65). However, their influence might be somewhat limited due to the weight of national political institutions and actors (D’Arcy 2013: 221).

„The influence of external actors works best where engagement with domestic political and policy processes enable stronger ownership of social protection programs by national governments, public administrations, and political constituencies, and

\footnotetext{
${ }^{4}$ This is somewhat in contrast to world polity theories (e.g., Krücken 2005), which conceptualise international organizations as important vectors for the diffusion of a set of fundamental norms and principles and models.
} 
where external knowledge is framed as learning rather than policy transfer" (NiñoZarazúa 2012: 169).

Politicians frequently share with donors a focus on national development based on economic growth. Nevertheless, when neglecting domestic politics donors might cause passive resistance or an active veto.

Finally, there are other theories that focus on the shaping of social policies by development strategies or production regimes (Ulriksen 2012). While these theories without doubt have their merit for cross-country comparison, they are less useful for explaining policy change within a country that happens frequently without corresponding changes in the economic policies. Focusing on a case study of Kenya, the next sections discuss free health care reforms (section 2), health insurance reforms (section 3) and the explanatory power of the five theoretical arguments discussed above to explain these reforms (section 4).

\section{The Politics of Free Health Care Reforms in Kenya}

A case study of Kenya has been conducted in order to shed some light on the politics of (failed) health care reforms. The case study is based on the scholarly literature, government reports and interviews with representatives of unions and associations of health professionals, and related members of civil society in January and February $2014 .^{5}$ These stakeholders have indepth knowledge on one health care reform (free maternity) introduced in 2013. The case study is furthermore informed by debates in the media followed systematically since 2012 and observations in Kenya made during various field trips since 2006.

\section{From free health care after independence to the donor-driven introduction of user fees}

Free health care can be universal, categorical (for mothers, for children, for certain diseases, etc.) or means tested. As in several other African countries, the 1963 independence of Kenya was also a „window of opportunity” for the introduction of universal free health care for all. The sessional paper $\mathrm{N}^{\circ} 10$ stated in 1965 that

"the declared aim of the Government is to provide medical and hospital services, old age and disability benefits, free and universal primary education, benefits for the unemployed, and financial aid to all who need and merit it for university work" (Republic of Kenya 1965: 30).

\footnotetext{
${ }^{5}$ These stakeholders have an in-depth knowledge of policy issues combined with access to administration and politicians. They were preferred as interview partners because the political parties are generally too weakly organised to serve as significant interview partners that could provide information beyond the public declarations already available. Health workers are further away from administration and politics and are thus less appropriate as interview partners. Before fieldwork, a list of stakeholders to be contacted was compiled. This was done by systematically scanning a Kenyan newspaper and other sources for names of unions and associations involved in public discussions around (maternal) health issues. Ten stakeholders were interviewed with the assurance of anonymity to ensure they would provide information as openly as possible. The interviews are anonymized with a interview number following the year they have been conduced (e.g., 14-06). All stakeholders supported the declaration of free maternity care, but provided differing explanations of this policy reform. Two stakeholders did not respond to attempts to contact them, one interview failed as the stakeholder was absent.
} 
This was depicted as the objectives of African Socialism, a quite misleading term, as Kenya turned out to become rather the antithesis of socialism. In 1965 the user fee of five shillings was abolished and thus, with few excepted services, free medical services for outpatients and all children were announced (Gsänger 1994: 10; Mwabu 1995: 248; Republic of Kenya 2012a: 4). This policy subsequently „saw a rapid expansion of the healthcare infrastructure, particularly in the 1970s and 1980s, and advances in health and social indicators" (Wamai 2009: 137).

Towards the end of the 1970s, a fast growing population and the growing effects of HIV increasingly put pressure on a health system that had a mounting urban bias (Gsänger 1994: 10). With increasing financial problems, the Kenyan government announced user charges in the Fourth Development Plan (1979-1983) (Wamai 2009: 139). This intention was part of the subsequent two development plans (1983-1988 and 1989-1993), but after a public outcry the government used the more acceptable term of ,introduction of cost-sharing” to communicate the same thing: the end of free health care (Mwabu 1995: 248).

A cost sharing scheme was finally hastily introduced in 1989, under „considerable pressure from donors" (Mwabu 1995: 248). The scheme was progressive in the sense that health care was for free at dispensaries, and then costs to be paid before treatment increased with the level of health care (Gsänger 1994: 10). After only nine months of implementation, the suspension of outpatient fees was abruptly communicated in the mass media. The reason was that media reported the disastrous effects of the fees on the poor and vulnerable and the government came under pressure. It is unclear if the imminence of the first multiparty-elections, in December 1992, also played a role. However, in April 1992, shortly after the suspension, the Kenyan government announced the reintroduction of facility-dependent outpatient fees, again through mass media (Gsänger 1994: 10; Mwabu 1995: 248). In reaction to the media reports, the new fees were to be charged after the patient was treated. There was some social cushioning, but with unclear criteria (van Lente 2004: 16). However, there were no protests anymore (Mwabu 1995: 252).

\section{Policy changes after multiparty elections}

The elections of 2002 ended the rule of the KANU party, in power since independence and sole legal party for twenty years. Charity Ngilu, the Minister of Health in the government of the new president Mwai Kibaki, introduced a new fee structure for primary healthcare facilities with a minimal user fee. "The public declaration did not have any detail or guidelines, neither was the fee system above the health centre level addressed" (Wamai 2009: 142). Charity Ngilu seems to have declared free maternity ahead of the 2007 elections. However, there is not enough information on this declaration and the policy change seems to have been bogged down in the context of post-election violence in the same year.

Categorical free health surely was introduced on 1 June 2013. The newly elected Kenyan president Uhuru Kenyatta declared, on the occasion of the Madaraka Day celebrations, that his government „has made adequate budgetary arrangements to enable all pregnant mothers to access free maternity services in all public health facilities" (Daily Nation, 01.06.2013). What was called „free maternity” was presented as a first step towards achieving free primary 
health care for all Kenyans. This has been part of the newly elected Jubilee Coalition's election manifesto (Jubilee Coalition 2013: 23). ${ }^{6}$

There is no doubt that in Kenya there are problems with health care in general and maternal health care in particular. The country performs rather poorly compared to its East African neighbours in attaining the health-related UN Millennium Development Goals (MDG). Two years ahead of the deadline, its under-five mortality rate of 73 children out of 1,000 births was the second highest in East Africa after Burundi and ranked 33rd globally (Ligami 2013). In contrast to neighbouring countries such as Tanzania, Uganda and nearby Rwanda, there has been less amelioration in recent years. Between 1948 (262 per 1,000 live births) and 1988 (89.2 per 1,000$)$, the under-five mortality rate improved, but, with increased poverty and cost sharing due to structural adjustment programmes, started to deteriorate afterwards (Ikamari 2004: 10; see also Atieno and Ouma Shem 2007). ${ }^{7}$ After 1998, the rate started to decline again to reach 73 per 1,000 in 2012, according to a World Bank database. As usual, data on the national level obscure important regional differences within Kenya (Otieno and Kibet 2013). One example is Kisumu county with a rate which is triple the national average and stands at 220 per 1,000 (Otieno 2012). The second health-related MDG is measured with maternal mortality rates. These rates show similar waves in Kenya, but its regional differences show another pattern.

The need to tackle the comparatively high rates of maternal and child mortality in Kenya is however not new and a functionalist perspective can thus hardly explain the decision to introduce free maternity health care. Free maternity care was poorly planned, and the quality of health care decreased after the declaration, which might even have had counterproductive effects (Künzler 2014). How can this policy change then be explained? The stakeholders interviewed explained the introduction of free maternity care mainly in terms of domestic political factors. According to several stakeholders, the introduction of free maternity care soon after the elections portrays the new president as an action man. "Jubilee wanted to show they are out there to implement", as a trade unionist put it (interview 14-05). This message of action was also symbolically communicated by President Kenyatta and his deputy William Ruto. After taking office, they repeatedly appeared without jackets and with their shirtsleeves rolled up (Standard 18.07.2013). ${ }^{8}$ The 2013 election that brought the new government to power was seen as flawed by many Kenyans (Long et al. 2013: 150f.). However, no stakeholder described the introduction of free maternity care as an attempt to cope with this situation and win domestic legitimation.

Free maternity care fulfils an electoral pledge. This was initially mentioned by several stakeholders; however, they added a reason why free maternity was chosen out of a wide range

\footnotetext{
${ }^{6}$ In the 2013 presidential election, there was no clear incumbent, as both Raila Odinga and Uhuru Kenyatta served in the sitting government, but it was rather Kenyatta who was held responsible for the performance of the past government (Ferree, Gibson, and Long 2014: 154).

${ }^{7}$ The quality of the data cited here is problematic, as they sometimes diverge when using different sources. However, the numbers are cited here less concerned with the idea of giving an accurate estimation of the situation, but more with substantiating trends.

${ }^{8}$ This image of the president as an action man is reminiscent of the description of former president Daniel arap Moi by Hornsby (2012: 582): „Although he was tribalist and authoritarian, aspects of his personality still appealed to Kenyans: the patriarch, the populist, the man of action".
} 
of electoral pledges: it can be implemented quickly and there is cross-cutting approval for this move. Or, in the words of a representative of a non-governmental organisation (NGO) in the health sector: „It was a strategic move to win the heart of the people very quickly" (interview 14-06). This valence issue "is a juicy carrot" (interview 14-04), appealing to voters. However, this "catchy political statement" (interview 14-09) does not refer to the electoral pledge in the manifesto before the 2013 elections, but to the actual declaration after the elections, and thus for the next elections. In the words of one stakeholder (interview 14-01), „they are keen on retaining power" with this move that appeals to the masses.

The declaration of free maternity care was less described as policy reform, but more as the continuation of policy reforms started by the previous government. Indeed, as mentioned by some stakeholders, free maternity care was already mentioned in the national development strategy, Vision 2030, that promised that the "government will provide access to those excluded from health care due to financial reasons" (Republic of Kenya 2007: 18). However, the focus of Vision 2030 is more on preventive health care. The Jubilee Coalition thus picked rather selectively one issue out of this policy document and did not refer to its entire health development strategy. Nevertheless, it is generally acknowledged that the manifestos of Jubilee and those of other coalitions were indeed heavily inspired by Vision 2030 (see, e.g., Makabila 2013).

A unionist said free maternity care is „a move closer to the constitution” (interview 14-05). Also, other stakeholders linked it with the new Kenyan constitution of 2010 that guarantees every Kenyan the highest attainable standard of health, including the right to access health care services (Republic of Kenya 2010, Art. 43(1)a). In the public perception, however, the main focus of the new constitution is rather the containment of the presidential authority than the aspirational recognition of second-generation human rights. ${ }^{9}$ Again, there are other human rights mentioned in the constitution that could have been addressed with a policy change and this line of argument is thus not exhaustive.

\section{The Politics of Health Insurance Reforms in Kenya}

An alternative policy choice to ease the financial burden of accessing health care is health insurance. In a first step, the coverage of diverse forms of insurances in the health sector is reviewed. A subsequent section then discusses reforms that aim at an expansion of the main insurance fund.

\section{Hospital and Health Insurance in Kenya}

In 1966, one year after free medical services for outpatients were introduced, the Kenyan government also established the National Hospital Insurance Fund (NHIF). Mandatory for workers in the formal sector, this was the first of its kind in sub-Saharan Africa (Koltermann 2004: 14). Government, however, actually announced its intention to introduce a broader National

\footnotetext{
${ }^{9}$ The crisis and the post-electoral violence after the elections of 2007 forced the political elite to find a consensus, and thus made the new constitution possible (Mati 2013: 235). Besides this, there was also pressure from below and from the international community.
} 
Health Insurance Fund (Republic of Kenya 1965: 30). Why this fund has been reduced to covering only hospital-based health care must be revealed by further research.

The Kenya Social Protection Sector Review (Republic of Kenya 2012a: 13, 18) is somewhat unclear and lists in one place 2.7 million contributing members of the NHIF, and in another only 367,886 . Probably, the first number refers to NHIF members working in the formal sector and the second to members working in the informal sector. This corresponds to the numbers cited in a report prepared for the World Bank and the Kenyan government by a private consulting company (Deloitte Consulting 2011: 19): a membership of 2.3 million in the formal sector and 0.5 million in the informal sector. Including the dependents of this total of 2.8 million members, an estimated 6.6 million Kenyans, or 17\% of the total population of 38.6 million (2009 census), are covered by the NHIF. ${ }^{10}$

Salaried employees see their mandatory contribution automatically deducted from their pay cheque, based on a graduated income-based scale. The NHIF contributions favour workers with higher incomes, as the scale has a salary ceiling after which the contribution does not rise any more. „The contribution is only on the salary portion of income - 'allowances', which can make of half or more of most government employees income, are exempt" (Fraker and Hsiao, 2007: 53). The NHIF board chairman estimates the number of salaried employees not covered by the NHIF at two percent (Jamah 2014: 18). There are no independent estimates, which would be difficult by nature anyway. For self-employed and informal sector workers, membership is voluntary and based on a flat rate that covers their nuclear families. Not included in the initial NHIF, voluntary membership was already incorporated in the 1972 act, but not implemented until 2005 (Chuma and Okungu 2011: 5).

However, there are substantial co-payments even for members of the NHIF. Furthermore, the fund covers only part of the health expenses and does not cover many of the health facilities that are mainly accessed by poor people. Frequently, Kenyans have low trust in the NHIF. For years, the majority of the contributions were used to cover excessive administrative costs and financed dubious investment projects, and only a small part of the budget benefitted members (Koltermann, 2004: 14; Fraker and Hsiao, 2007: 52f.). The benefits to members were only recently increased to more than half of the budget. Adding to this is an ongoing series of corruption scandals, lack of transparency in deals, and confusion over the sacking and reinstatement of upper management. A cumbersome reimbursement process prone to fraud and abuse is also contributing to a general feeling of paying contributions without getting adequate benefits (Koltermann 2004: 14).

The NHIF administers a special medical scheme for civil servants and their nuclear families, including up to three children. This scheme covers inpatient and outpatient medical services in accredited hospitals, including some mission and private hospitals. ${ }^{11}$ Optical and dental coverage is also provided, and for the principal member life insurance and coverage for burial expenses graduated according to wage groups. The scheme is funded in two ways. First,

\footnotetext{
${ }^{10}$ As the notion of dependents suggests, their protection depends on their relation to the bread-winning head of the household.

${ }^{11}$ While the Ministry of Public Service wanted a consortium of at least five underwriters to administer the scheme, its counterpart of Medical Services opted for the NHIF - not without allegations of corruption - and was finally supported by the government (Amani 2011; Limo 2012).
} 
by the monthly medical allowance that is directly fed into the scheme, and second, the government adds additional funds. The health expenses of an already rather privileged group are thus doubly supported by taxpayers. Similar schemes as the one for civil servants are also offered by the NHIF for other professional groups and employers.

Other employers contract the health care schemes for their employees to private insurance companies. It is difficult to assess how many Kenyans are covered by such schemes. Numbers from 2007 include individuals insured by private companies and estimate membership at about 600,000 Kenyans (Chuma and Okungu, 2011: 6) or less than $2 \%$ of the population. ${ }^{12}$ It should be remembered that since the 1990s, several private health insurance schemes have collapsed (World Bank, 2010: xv). For a long time, there was only private health insurance with high premiums targeting a rather rich group that benefitted from tax relief. As employment-based health insurance ends with retirement, there are also medical savings plans for the post-retirement life. Private insurance companies recently discovered business opportunities provided by the workers in the informal sector and started offering low-cost health insurance products. They use different sales channels (e.g., mobile money, banks) to collect rates ranging from KSh 300 to KSh 1,000 for schemes that differ in coverage (inpatient and outpatient benefits, life coverage, funeral expenses, paid sick days). While many of these schemes are in competition with the NHIF, others are in collaboration with it.

Micro-insurance, in the form of Community Based Health Insurance (CBHI), is another possibility for workers in the informal sector, in which women and young Kenyans are overrepresented. CBHI premiums are within the lower range of low-cost private insurance. Since its introduction in 1999, a number of CBHI schemes emerged. However, there are no recent data about the number of beneficiaries. Not much is known about other micro-insurance initiatives beyond these CBHI schemes.

\section{Reforming the NHIF}

A major attempt to broaden the coverage of the NHIF by making it gradually compulsory was made after the accession to power of the National Rainbow Coalition (NaRC) government in 2002. A new National Social Health Insurance Fund (NSHIF) was proposed to replace the NHIF. Advised by the World Health Organization (WHO) and the then Deutsche Gesellschaft für Technische Zusammenarbeit (GTZ), the contribution structure was three-tiered and based on the idea of solidarity: the money from 5\% value-added tax should finance the contribution of the poorest $30 \%$ of Kenyans, for half of the population there was a flat-rate contribution and finally, $20 \%$ of the population made up by contributing employees would have half their contribution paid by their employers (Koltermann, 2004: 15). A highly controversial corresponding bill was passed by the parliament in December 2004, but president Mwai Kibaki declined to sign it into law "citing problems related to technical design, affordability, implementation and sustainability" (Abuya et al. 2015: 6).

What are the reasons for this? During research in Kenya, it was repeatedly attributed by different sources to the resistance of the private insurance sector worried about losing busi-

\footnotetext{
${ }^{12}$ At the time of writing (May 2015), a proposed medical coverage for teachers awarded to a private insurance company was legally contested.
} 
ness opportunities. Among the shareholders of companies in this sector are the Kibaki family and allegedly also other members of the government. There was also pressure against NSHIF from the treasury and some donors to limit state spending (Hornsby 2012: 737, Abuya et al. 2015: 7f.). Furthermore, organizations representing the employees of the formal sector - including health professionals and teachers - were against the NSHIF (Wamai 2009: 152; Maupeu 2012: 60f.). They feared that their members - part of the middle class - were to be plucked by taxes and contributions in the name of financing the health insurance of the poorer. Many preferred a system where the NHIF, which they saw as untrustworthy, would be reduced to a very basic form of health insurance and more extensive coverage would be offered by private insurances of their choice. The latter would be financed by the medical allowances - in the case of teachers - or by individual resources and benefit from tax relief.

Another reform attempt was initiated in 2007. In April 2008, a government of national unity was formed as a consequence of the eruption of violence after the 2007 elections. This "grand coalition cabinet" had two ministries responsible for health: while the minister of Public Health and Sanitation was a member of the incumbent president Mwai Kibaki's Party of National Unity, her counterpart from the Ministry of Medical Services belonged to the oppositional ODM. In this context, no bill was taken to the parliament (Wamai 2009: 155f.). In addition to earlier reservations by president Kibaki, his party had no interest in letting the opposition credit themselves with major health insurance reform. In June 2008, the country's new development programme, Vision 2030, was officially launched. It was based on a consultation process that started in 2006 and announced the creation of a National Health Insurance by 2012, without elaborating on its design (Republic of Kenya 2008: 18). Consequently, a new sessional paper (No. 7) on „Universal Health Coverage” proposed the transformation of the National Hospital Insurance Fund (NHIF) into a National Health Insurance Fund and government contributions on behalf of the indigents. This paper failed to pass through parliament in 2012 towards the end of Kibaki's second and final term.

While health care was part of the election manifestos by the main contending coalitions and parties for the 2013 elections (Amani Coalition 2013; Coalition for Reforms and Democracy (CORD) 2013; Jubilee Coalition 2013; Kenneth 2011 for Eagle), only two of them (CORD and Eagle) were advocating, unsuccessfully, for a universal health insurance. Currently, discussions over what is frequently unprecisely termed „universal health coverage” continue in Kenya. At the sub-national level, some counties have made steps in this direction by declaring NHIF registration compulsory or supporting the NHIF contributions of elderly citizens. This decentralisation of social security needs further attention.

\section{The Politics of (Failed) Reforms in Kenya}

To sum up the preceding two sections, the vast majority of Kenyans still are not covered by any kind of health insurance. Several attempts to broaden the coverage of the NHIF have failed. There have been alternating reforms introducing and abolishing universal or categorical forms of free health care. Are the theoretical explanations presented able to explain these reforms, their undoing and failure? 


\section{Drivers and breakers of social policy reforms in Kenya}

The introduction, expansion or abolition of free health care or health insurance on the national level is defined as a reform for the purposes of the following discussion. Both free health care and health insurance can be universal, or categorical/sectoral. This is of course a rather demanding understanding of reforms that goes beyond explaining incremental change. Furthermore, this perspective ignores the (gendered) effects of such reforms.

Several Kenyan reforms fit well into the windows of opportunity argument. The introduction of free health care for all and the establishment of the NHIF occurred at a moment when the political system was open (after independence), so did the introduction of free maternity care (change of government). ${ }^{13}$ However, the window of opportunity presented by the election of Mwai Kibaki did not lead to a social policy reform (introduction of NSHIF), but rather to a failed reform attempt. Neither created the introduction of the government of national unity in the context of post-electoral violence a window of opportunity for a reform, quite to the contrary; this government where the responsible Ministry of Health belonged to the opportunity, rather turned out to create a ,window of inopportunity".

The introduction of free health care for all and the establishment of the NHIF after independence fit into the electoral cycles argument. They were introduced, in accordance with Niles (1999: 10f.), by elected authoritarian systems and targeted, in accordance with Hickey (2010), a limited clientele. However, the introduction of free maternity care after the election of Uhuru Kenyatta contradicts both arguments. First, this reform targets mothers who are in this perspective generally not seen as a category critical for the survival of a government. Second, it was implemented in a fragmented party system where reforms are supposedly unlikely. However, even in the context of prevailing ethnic voting, when there are electoral stalemates or fragile majorities, key social policies with a catch-all appeal might be implemented by newly elected presidents in order to promote re-election. Several interviews with stakeholders clearly pointed in this direction. Even highly personalised parties with a strong ethnic appeal, thus might not only have manifestos, but also realize a few strategically selected pledges. A similar example mentioned in several interviews was the declaration of free primary education after the 2002 elections (Künzler 2007). ${ }^{14}$ Finally, again, the NSHIF was not introduced although it would have fit in the election cycle of Kibaki.

The introduction of free maternity care did not trigger a veto either. President Kenyatta's justifications for this policy are in line with a frequent concern of "African elites who see economic growth as the priority for national development" (Niño-Zarazúa et al. 2012: 169) and describe women as important economic drivers that contribute to economic development. Indeed, the president avoided using a rights-based argument to justify his health policy. Rather, he framed health as a contribution to development (Chai 2013): „We know that if Kenyans are healthy, we will be in a better position to achieve our development goals." This perspective is, however, not new, as free health services as part of a development strategy was

\footnotetext{
${ }^{13}$ The new fee structure as introduced after the elections in 2002 by the new government is an example of gradual policy change and does not qualify as reform as it is understood here.

${ }^{14}$ Here, the newly elected president Kibaki was in need of support, as he was soon going to alienate the electoral basis of his main ally Odinga. Retrospectively, Kibaki is still credited with this flagship social policy reform, its shortcomings notwithstanding.
} 
already a preoccupation of the Kenyan government after independence (Atieno and Ouma Shem 2007: 180f.).

The failed introduction of the NSHIF can ex post be explained by the veto of powerful policy actors, such as the then president, some ministers, the private sector, formal sector workers and some donors. Indeed, the role of donors is ambiguous, as other donors pushed unsuccessfully for this reform. Donors then again were successful when they pushed for the introduction of a cost sharing scheme at the end of the 1980s. In this period, both the Bretton Woods institutions with their Structural Adjustment Programs as well as the WHO and UNICEF with their Bamako Initiative (1987) supported user fees in the health system. Furthermore, there was no veto by the Finance Minister as there was pressure to cut government spending. While some donors, especially the WHO, were concerned with universal health coverage and saw user fees as obstructive to this goal, the Bretton Woods institutions still were concerned about government spending and supported - as did some other donors such as USAID - private sector health investments. ${ }^{15}$ However, this did not prevent the World Bank from giving Kenya a loan with universal health coverage in view (World Bank 2013).

Free maternity care surely is in accordance with the international agenda. It is not only seen as a tool to reach the health related MDGs, but it is also concurrent with a general trend in the international community towards free health care (Robert and Ridde 2013, see also the introduction to this special issue for a discussion of gobal influences in the health domain). Stakeholders differed in their views on the influence of the international community on the declaration of free maternity care. The most obvious influence at the international level was indirect. The argument used by political actors in their manifestos, by the ruling coalition in their policy reform, and by the stakeholders - who form a rather homogeneous sample of professionals - in the interviews is framed concurrently with the international agenda. Yet another reform, the initial introduction of free health care after independence, however, predated the international consensus reached with the Alma Ata declaration of 1978 highlighting the importance of primary health care.

The role of donors in Kenya is ambiguous beyond social policy. On one hand, there are clear signs of pressure, e.g., to implement power sharing after the post-electoral violence in 2008 , to draft a new constitution, or to tackle corruption in the educational sector. On the other hand, „if the past is any guide, donors are unlikely to maintain intense political pressure over time, shifting instead to economic and security priorities once again” (Brown 2009: 399). Kenya is an important ally of the western countries in their "war on terror" and on maritime piracy. Consequently, according to Brown and Raddatz (2014: 43), there is a „consistent pattern of donors not enforcing stated conditions for future support".

As mentioned, donors are supposed to have more influence where there is stronger domestic ownership and their policies are framed as learning and not policy transfer (NiñoZarazúa 2012: 169). Indeed, there is a thin line between donor influence and ideational policy learning. As mentioned, free maternity care is concurrent with a general trend in the international community. Introducing it might just as well be the result of ideational policy learning, given there are numerous studies showing the negative effects of user fees on the utilisation of

\footnotetext{
${ }^{15}$ Universal health coverage is important not only to reach the Millennium Development Goals, it is also central to the World Health Reports of 2008 and 2010 and the Abuja Declaration of 2001 aimed at financing it.
} 
health facilities. The same is true for the introduction of user fees in the health system, where again numerous studies advocated for this policy change in accordance with the Bamako Initiative. It would take more research to judge whether the introduction of free health care after independence was some kind of ideational policy learning. However, as socialist and nonsocialist both did and did not introduce free health care in sub-Saharan Africa, there might be other factors behind it. It is difficult to evaluate whether there is evidence of cross-national policy learning.

\section{Conclusion}

The summary of the results in table 1 shows clearly that there is no single explanation of social policy reforms or their failure. While a window of opportunity seems to be a necessary condition for expansive reforms, it is not for contractive reforms. It is not a sufficient condition, as there are also failed reforms not profiting from an existing window of opportunity. While the absence of a veto seems to be a necessary condition for expansive reforms, the presence of a veto helps explain reform failure along with other factors. However, there are not yet enough data to assess the effect of a veto or its absence. Donors are associated with expansive reforms, contractive reforms and failed reforms. The same is the case for election cycles. Finally, universal reforms are neither more difficult nor easier than categorical, as they succeeded both in their expansive and contractive forms, but also failed. Indeed, there seem to be different combination of factors at work. Most empirical studies on the politics of social policy in Africa tend to neglect this, as they either do not systematically consider the same factors for explanation or are limited to systematically evaluting only one factor.

These results have certain limits. The definition of reform used above does not include incremental changes such as changes in the NHIF contributions. The content of (failed) reforms and their effects are also not discussed. Nevertheless, this case study revealed how different configurations (occurrence or absence of several factors) are related to the same outcome (equifinality), respectively how one factor might lead to different outcomes (multifinality), depending on the configuration. While such a case studies of social policy reforms has its merits, a comparative perspective of several countries or even a systematic analysis of reforms, their undoing and their failure across sub-Saharan Africa would further strengthen the argument and provide an empirical basis for a theory that considers combinations of factors. ${ }^{16}$

\footnotetext{
${ }^{16}$ Another potentially fruitful path for further research is the analysis of other policy domains such as old age, agricultural or educational policies. There is no reason why election cycles for example should be limited to only one policy domain.
} 


$$
\begin{array}{ccc}
\text { Reform: expansi- } & \begin{array}{c}
\text { Reform: } \\
\text { on }
\end{array} & \text { Failed reforms } \\
\text { contraction } &
\end{array}
$$

\begin{tabular}{|c|c|c|c|c|c|c|c|}
\hline & 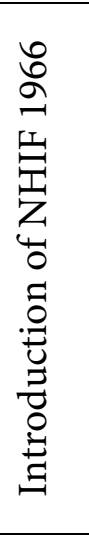 & 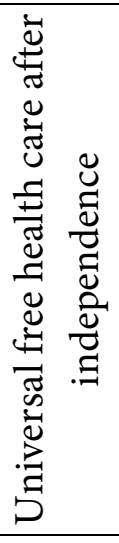 & 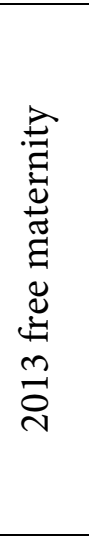 & 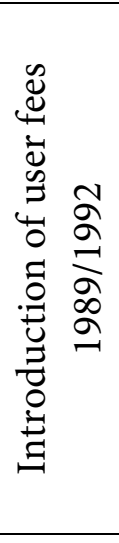 & 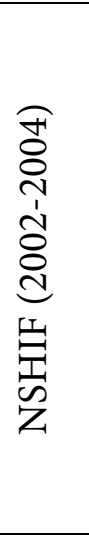 & 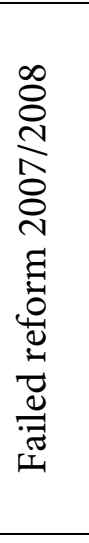 & 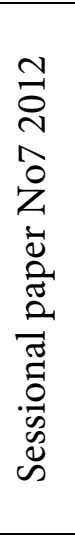 \\
\hline Windows of opportunity & 1 & 1 & 1 & 0 & 1 & 1 & 0 \\
\hline Openness (indep./end of minority & 1 & 1 & 0 & 0 & 0 & 0 & 0 \\
\hline rule) & 0 & 0 & 1 & 0 & 1 & 1 & 0 \\
\hline Openness (change of government) & 0 & 0 & 0 & 0 & 0 & 0 & 0 \\
\hline Openness (civil war) & 0 & 0 & 1 & 0 & 0 & 0 & 0 \\
\hline \multicolumn{8}{|l|}{$\begin{array}{l}\text { Resources (donors, economic } \\
\text { boom) }\end{array}$} \\
\hline Policy learning & 0 & 0 & 1 & 1 & 1 & 1 & 0 \\
\hline Ideational learning $(+/-)$ & 0 & 0 & 1 & 1 & 1 & 0 & 0 \\
\hline Instrumental learning $(+/-)$ & 0 & 0 & 0 & 0 & 0 & 0 & 0 \\
\hline Strategic learning $(+/-)$ & 0 & 0 & 0 & 0 & 0 & 1 & 0 \\
\hline Political business/election cycles & 1 & 1 & 1 & 1 & 1 & 1 & 0 \\
\hline Elected authoritarian $(1965 / 1992-$ & 1 & 1 & n.a. & 0 & n.a. & n.a. & n.a. \\
\hline 2002) & 0 & 0 & 0 & 1 & 0 & 0 & 0 \\
\hline Non-electoral (1969-1988) & n.a. & n.a. & 1 & n.a. & 1 & 1 & 0 \\
\hline \multicolumn{8}{|l|}{$\begin{array}{l}\text { Fragmented party democracy } \\
(2002-)\end{array}$} \\
\hline Veto (including donors) & * & 0 & 0 & * & 1 & * & * \\
\hline Pro-reform donors & 0 & 0 & 1 & 1 & 1 & * & * \\
\hline
\end{tabular}

Table 1: Summary of the Results. Note: 1 present, 0 absent, ${ }^{*}$ no information, n.a. not applicable 


\section{References}

Abuya, Timothy, Thomas Maina and Jane Chuma (2015). Historical account of the national health insurance formulation in Kenya: experiences from the past decade. BMC Health Services Research, 15(56), 1-11.

Amani Coalition (2013). Manifesto 2013. "Kenyans Have Spoken"/“Wakenya Wasema ni Amani”. No longer available online.

Anami, Luke (2011). How private insurance companies lost the deal. Standard 30.12.2011. Accessed 30.05.2012 on www.standardmedia.co.ke/print/2000049221/how-private-insurance- companieslost-the-deal (link no longer active).

Anonymous (2013). Jubilee’s Fulfilled Pledges, Missed Targets after 100 days. Standard 18.7.2013, 2.

Atieno, Rosemary and Alfred Ouma Shem (2007). The Role of Social Policy in Development: Health, Water and Sanitation in East Africa. In: Adésínà, Jimi O. (ed.). Social Policy in Sub-Saharan African Context. In Search of Inclusive Development (171-197). Basingstoke/New York: Palgrave Macmillan.

Bender, Katja (2013). The Political Economy of Social Protection Reforms in Developing Countries. What is to be explained and how? In: Bender, Katja, Markus Kaltenborn and Christian Pfleiderer (eds.). Social Protection in Developing Countries. Reforming Systems (33-42). London/New York: Routledge.

Block, Steven A. (2002). Political Business Cycles, Democratization, and Economic Reform: The Case of Africa. Journal of Development Economics, 67(1), 205-228.

Bratton, Michael and Mwangi S. Kimenyi (2008). Voting in Kenya: Putting Ethnicity in Perspective. Journal of Eastern African Studies, 2(2), 272-289.

Brown, Stephen (2009). Donor Responses to the 2008 Kenyan Crisis: Finally Getting it Right? Journal of Contemporary African Studies, 2(3), 389-406.

Brown, Stephen and Rosalind Raddatz (2014). Dire Consequences or Empty Threats? Western Pressure for Peace, Justice and Democracy in Kenya. Journal of Eastern African Studies, 8(1), 43-62.

Buse, Kent and David Booth with Grace Murindwa, Aziza Mwisongo and Andrew Harmer (2008). Donors and the Political Dimensions of Health Sector Reform: The Cases of Tanzania and Uganda. Good Governance, Aid Modalities and Poverty Reduction: Linkages to the Millennium Development Goals and Implications for Irish Aid, Working Paper no.7. Accessed 31.01.2016 on www.odi.org.uk/resources/download/3361.pdf.

Carbone, Giovanni (2011). Democratic demands and social policies: the politics of health reform in Ghana. Journal of Modern African Studies, 49(3), 381-408.

Casey, Bernard H. and Roddy McKinnon (2009). Social pensions and policy learning: The case of southern Africa. International Social Security Review, 62(4), 81-102.

Chai, Kazungu (2013). Uhuru Reassures Healthcare Part of His Agenda. Standard 14.08.2013, 2.

Chuma, Jane and Vincent Okungu (2011). Viewing the Kenyan health system through an equity lens: implications for universal coverage. International Journal of Equity in Health, 10(22). Accessed 16.01.2016 on http://www.equityhealthj.com/content/10/1/22. 
Coalition for Reforms and Democracy (CORD) (2013). Manifesto. Unleashing Kenya's Potential, presented on 28 January 2013. No longer available online.

Cometto, Giorgio, Gyuri Fritsche and Egbert Sondorp (2010). Health sector recover in early postconflict environments: experience form southern Sudan. Disasters, 34(4), 885-909.

Corrêa, Diego Sanches and José Antonio Cheibub (2016). The Anti-Incumbent Effects of Conditional Cash Transfer Programs. Latin American Politics and Society, 58(1), 49-71.

Daily Nation (2013). Kenya Rolls out Free Maternal Care. Daily Nation 01.06.2013. Accessed 02.06.2013 on https://www.facebook.com/DailyNation/posts/10151682246714497.

D'Arcy, Michelle (2013). Non-state actors and universal services in Tanzania and Lesotho: state-building by Alliance. Journal of Modern African Studies, 51(2), 219-247.

Deloitte Consulting (2011). Strategic Review of the National Hospital Insurance Fund - Kenya. Accessed 21.08.2014 on https://www.wbginvestmentclimate.org/advisory-services/health/upload/ Kenya-Strategic-review-of-the-NHIF-final_cv.pdf.

Devereux, Stephen and Philip White (2010). Social Protection in Africa: Evidence, Politics, and Rights. Poverty \& Public Policy, 2(3), 53-77.

Elischer, Sebastian (2010). Political Parties, Elections and Ethnicity in Kenya. In: Branch, Daniel, Nic Cheeseman, and Leigh Gardner (eds.). Our Turn to Eat. Politics in Kenya since 1950 (199-220). Berlin/Münster: Lit Verlag.

Ellis, Frank, Stephen Devereux and Philip White (2006). Social Protection in Africa. Cheltenham: Edward Elgar.

Feng, Yi and Theodora-Ismene Gizelis (2002). Building Political Consensus and Distributing Resources: A Trade-Off or a Compatible Choice? Economic Development and Cultural Change, 51 (1), 217-237.

Ferree, Karen E., Clark C. Gibson and James D. Long (2014). Voting Behavior and Electoral Irregularities in Kenya's 2013 Election. Journal of Eastern African Studies, 8(1), 153-172.

Fraker, Andrew and William C. Hsiao (2007). Kenya: Designing Social Health Insurance. In: Hsiao, William C. and R. Paul Shaw (eds.). Social Health Insurance for Developing Nations (51-67). Washington: World Bank.

Gĩthĩnji, Mwangi wa and Frank Holmquist (2008). Kenya's Hopes and Impediments: The Anatomy of a Crisis of Exclusion. Journal of Eastern African Studies, 2(2), 344-358.

Gsänger, Hans (1994). Social Security and Poverty in Kenya. Developing Social Security Systems for Poverty Alleviation. Reports and Working Papers 8/1994. Berlin: German Development Institute.

Gutiérrez-Romero, Roxana (2010). Decentralization, Accountability and the 2007 MPs Elections in Kenya. University of Oxford, Centre for the Study of African Economies Series, Working Paper 2010-09. Accessed 24.05.2014 on http://www.csae.ox.ac.uk/workingpapers/pdfs/2010-09text.pdf.

Hall, Peter A. (1993). Policy Paradigms, Social Learning, and the State: The Case of Economic Policymaking in Britain. Comparative Politics, 25(3), 275-296.

Hickey, Sam (2009). The politics of protecting the poorest: Moving beyond the 'anti-politics machine'? Political Geography, 28, 473-483. 
Hickey, Sam (2010). Conceptualising the Politics of Social Protection in Africa. In: Barrientos, Armando, and David Hulme (eds.). Social Protection for the Poor and Poorest. Concepts, Policies and Politics (247-263). Basingstoke/New York: Palgrave Macmillan.

Hickey, Sam, Rachel Sabates-Wheeler, Bruce Guenther and Ian Macauslan (2009). Promoting Social Transfers: DFID and the Politics of Influencing. DFID Working Paper 32. London: Department for International Development. Accessed 31.01.2016 on https:/www.gov.uk/government/uploads/ system/uploads/attachment_data/file/67723/politics-influencing-working-paper-32.pdf.

Hornsby, Charles (2012). Kenya. A History Since Independence. New York: I.B. Tauris.

Ikamari, Lawrence D.E. (2004). An Upsurge in Early Childhood Mortality in Kenya: A Search for Explanations. African Journal of Health Sciences, 11(1-2), 9-20.

Jamah, Ally (2014). NHIF sets 25 million new members target by 2016. Standard 05.11.2014, 18.

Jubilee Coalition (2013). Transforming Kenya. Securing Kenya's Prosperity 2013-2017, The Shared Manifesto of the Coalition between the National Alliance (TNA), the United Republican Party (URP), the National Rainbow Coalition (NARC) and the Republican Congress Party (RC). Accessed 29.04.2014 on http://issuu.com/jubileemanifesto/docs/jubilee_manifesto.

Keeler, John T.S. (1993). Opening the Window for Reform. Mandate, Crises, and Extraordinary Policy-Making. Comparative Political Studies, 25(4), 433-486.

Kenneth, Peter (2011). Manifesto Peter Kenneth. Accessed 25.05.2014 on www.archivoelectoral.org/ archivo/doc/MAnifiestoPeterKennethKenyaNationalCongressPresidencialKenia2013.pdf.

Koltermann, Ulrike (2004). Health care for all. In: GTZ (ed.). Social Health Insurance - Systems of Solidarity. Experiences from German development cooperation (12-15). Eschborn: GTZ.

Krishna, Anirudh, Daniel Lumonya, Milissa Markiewicz, Firminus Mugumya, Agatha Kafuko and Jonah Wegoye (2006). Escaping poverty and becoming poor in 36 villages of Central and Western Uganda. Journal of Development Studies, 42(2), 346-370.

Krücken, Georg (2005) (ed.): John W. Meyer: Weltkultur. Wie die westlichen Prinzipien die Welt durchdringen. Suhrkamp, Frankfurt am Main

Künzler, Daniel (2007). "Nothing actually really changed"? Die kenianische Bildungsreform von 2003 im Lichte der sozialen Ungleichheit. Africa Spectrum, 42(3), 507-517.

Künzler, Daniel (2014). Free maternity in Kenya? The catch-all politics of social policy in Kenya. Paper presentation, XVIII International Sociological Association (ISA) Congress, 17.07.14. Yokohama, Japan.

Künzler, Daniel (forthcoming). Social security reforms in Kenya: Towards a workerist or a citizenshipbased system? International Social Security Review.

Ligami, Christabel (2009). Slow Progress in Battle to Cut Child Mortality in East Africa, East African 16.09.2009. Accessed 25.05.2014 on http://www.afrika.no/Detailed/24178.html.

Limo, Lucianne (2012). Atwoli wants Nyong'o sacked over Sh2.4b scam. Standard 21.06.2012. Accessed 21.06.2012 on http://www.kigalikonnect.com/article/kenya-atwoli-wants-nyongo-sacked over-sh24b-scam.html.

Long, James D., Karuti Kanyinga, Karen E. Ferree and Clark Gibson (2013). Choosing Peace over Democracy. Journal of Democracy, 24(3), 140-155. 
Lynch, Gabrielle (2014). Electing the 'Alliance of the Accused': The Success of the Jubilee Alliance in Kenya's Rift Valley. Journal of Eastern African Studies, 8(1), 93-114.

Makabila, Stephen (2013). Vision 2030: Party Manifestos Silent on Vital Funding, Standard on Sunday 10.02.2013, 22.

Marmor, Ted, Richard Freeman and Kieke Okma (2005). Comparative Perspectives and Policy Learning in the World of Health Care. Journal of Comparative Policy Analysis: Research and Practice, 7(4) 331-348.

Mati, Jacob Mwathi (2013). Antinomies in the Struggle for the Transformation of the Kenyan Constitution (1990-2010). Journal of Contemporary African Studies, 31(2), 235-254.

Maupeu, Hervé (2012). Classe moyenne kenyane et démocratie électorale. Mode de vie et revendication politique. Afrique contemporaine, 244, 53-68.

Meessen, Bruno, David Hercot, Mathieu Noirhomme, Valéry Ridde, Abdelmajid Tibouti, Christine Kirunga Tashobya and Lucy Gilson (2011). Removing user fees in the health sector: a review of policy processes in six sub-Saharan African countries. Health Policy and Planning, 28, ii16-ii29.

Meyer, David S. (2004). Protest and Political Opportunities. Annual Review of Sociology 30, 125-145.

Mwabu, Germano (1995). Health care reform in Kenya: a review of the process. Health Policy, 32, 245255.

Niles, Kimberley J. (1999), Economic Adjustment and Targeted Social Spending: The role of Political Institutions. Paper prepared for the World Development Report 2001 meetings, August 16-17, Castle Donington. Accessed 02.07.2014 on http://web.iaincirebon.ac.id/ebook/moon/ PoliticalScience/NILES_POLINSTITUTION.PDF.

Niño-Zarazúa, Miguel, Armando Barrientos, Samuel Hickey and David Hulme (2012). Social Protection in Sub-Saharan Africa: Getting the Politics Right. World Development, 40(1), 163-176.

Otieno Ajwang', Nicholas W. (2013). The Impact of Health Insurance on Houshold Access to Healthcare in Eldoret, Kenya. In: Devereux, Stephen, and Melese Getu (eds.). Informal and formal Social Protection Systems in Sub-Saharan Africa (231-257). Kampala: Fountain Publishers.

Otieno, Kepher (2012). Reproductive Health: Study Shows Rise in Mother, Infant Deaths. Standard 19.10.2012, 23.

Otieno, Rawlings and Lonah Kibet (2013). Kenya's Health Inequalities Wide. Standard 10.09.2013, 22.

Picard, Louis A. (1987). The Politics of Development in Botswana. A Model for Success? Boulder, CA/London: Lynne Rienner.

Presidential Debate (2013). Field Notes of the Presidential Debate. Shown on 8 TV Stations. Nairobi, 11.02.2013.

Republic of Kenya (1965). African Socialism and its Application to Planning in Kenya. [Nairobi]: Government Printer.

Republic of Kenya (2007). Kenya Vision 2030: The Popular Version. Accessed 31.01.2016 on http://www.konzacity.go.ke/wp-content/uploads/2014/12/Popular_Version.pdf.

Republic of Kenya (2010). Constitution. Accessed 01.08.2014 on http://www.kenyalaw.org:8181/ exist/kenyalex/actview.xql?actid=Const 2010 . 
Republic of Kenya (2012a). Kenya Social Protection Sector Review. Nairobi: Ministry of State for Planning, National Development and Vision 2030. Accessed 31.01.2016 on http://www.unicef.org/ evaldatabase/files/Kenya_Social_Protection_Sector_Review.pdf.

Republic of Kenya (2012b). Sessional Paper No. 7 of 2012 on the Policy on Universal Health Care Coverage in Kenya. Nairobi: Ministry of Medical Services. Accessed 31.01.2016 on http://www. universalhealth2030.org/index.php/documents-publications/category/3-kenya-health-system? download=35:Sessional\%20Paper\%20No.\%207\%20-\%20Universal\%20Coverage\&start=40.

Ridde, Valéry, Ludovic Queuille and Yamba Kafando (eds.) (2012). Capitalisations de politiques publiques d'exemption du paiement des soins en Afrique de l'Ouest. Montréal: Centre de recherche du centre hospitalier de l'université de Montréal (CRCHUM) et Allemagne [sic!]: Help - Hilfe zur Selbsthilfe e.V. Accessed 31.01.2016 on http://www.help-ev.de/fileadmin/media/ ExemptionPaiementEnAO-Capitalisations_296p__CRCHUM-HELP-ECHO_2012.pdf.

Robert, Emilie and Valéry Ridde (2013). Global Health Actors No Longer in Favor of User Fees: A Documentary Study. Globalization and Health, 9, 1-16.

Schmid, Achim and Ralf Götze (2009). Cross-national policy learning in health system reform: The case of Diagnosis Related Groups. International Social Security Review, 62(4), 21-40.

Seekings, Jeremy (2013). Social Policy. In: Cheeseman, Nic, David M. Anderson and Andrea Scheibler (eds.). Routledge Handbook of African Politics (309-321). Oxon: Routledge.

Tarrow, Sidney (1994). Power in Movement. Cambridge: Cambridge University Press.

Ulriksen, Marianne S. (2012). Welfare Policy Expansion in Botswana and Mauritius: Explaining the Causes of Different Welfare Regime Paths. Comparative Political Studies, 45(12), 1483-1509.

Van Lente, Evert-Jan (2004). A national act of courage. In: GTZ (ed.): Social Health Insurance - Systems of Solidarity. Experiences from German development cooperation (16-18). Eschborn: GTZ.

Wamai, Richard G. (2009). Healthcare policy administration and reforms in post-colonial Kenya and challenges for the future. In: Veintie, Tuija and Pirjo Kristiina Virtanen (eds). Local and Global Encounters: Norms, Identities and Representations in Formation (136-158). Helsinki: The Renvall Institute for Area and Cultural Studies.

Weyland, Kurt (2005). Theories of Policy Diffusion. Lessons from Latin American Pension Reform. World Politics, 57(2), 262-295.

World Bank (2010). Private Health sector Assessment in Kenya. Working Paper No. 193. Washington: World Bank. Accessed 31.01.2016 on http://www-wds.worldbank.org.

World Bank (2013). WB to Help Kenya Provide Better Health and Nutrition Services for 35 Million People by 2016. Press Release 30.12.2013. Accessed 08.06.2014 on http://www.worldbank.org/.

World Bank (n.d.). Database: Mortality Rate, Under-5 (per 1,000 Live Births). Accessed 04.06.2014 on http://data.worldbank.org. 